\title{
Viver no território ocupado: entrevista com Baha Hilo e Sandra Guimarães
}

\author{
Living under occupied territory: Interview with Baha Hilo and Sandra Guimarães \\ Viviendo en el territorio ocupado: entrevista con Baha Hilo y Sandra Guimarães
}

\begin{abstract}
Resumo: Nesta entrevista realizada por Daniela Rosendo e Fabio A. G. Oliveira, no dia 4 de junho de 2021, os/as entrevistados/as Baha Hilo, sociólogo palestino, e Sandra Guimarães, brasileira militante de direitos humanos e animais que viveu e atuou na Palestina, explicam a opressão do povo palestino perpetrada pelo Estado de Israel. Para tanto, relatam como funcionam os sistemas de segregação racial aplicados em diferentes regiões do território, as similaridades entre mecanismos de opressão tanto na Palestina quanto no Brasil, a importância da solidariedade política entre os povos do Brasil e da Palestina e o papel do boicote, além da denúncia às apropriações de Israel das causas LGBTQIA+ e animalistas.

Palavras-chave: colonialismo; ocupação militar israelense; Palestina; opressão; BDS.
\end{abstract}

\begin{abstract}
In this interview conducted by Daniela Rosendo and Fabio A. G. Oliveira, on June 4th, 2021, the interviewees Baha Hilo, a Palestinian sociologist, and Sandra Guimarães, a Brazilian human and animal rights activist who lived and worked in Palestine, explain the oppression of the Palestinian people perpetrated by the State of Israel. To this end, they report how the systems of racial segregation applied in different regions of the territory, the similarities between mechanisms of oppression in both Palestine and Brazil, the importance of political solidarity between the peoples of Brazil and Palestine, and the role of boycott, in addition to denouncing Israel's appropriations of LGBTQIA+ and animalist causes.
\end{abstract}

Key-Words: colonialism; israeli military occupation; Palestine; oppression; BDS.

Resumen: En esta entrevista realizada por Daniela Rosendo y Fabio AG Oliveira el 4 de junio de 2021, los entrevistados Baha Hilo, sociólogo palestino, y Sandra Guimarães, activista brasileña de derechos humanos y animales que vivió y trabajó en Palestina, explican la opresión del pueblo palestino, perpetrado por el Estado de Israel. Para eso, relatan cómo funcionan los sistemas de segregación racial aplicados en distintas regiones del territorio, las similitudes entre los mecanismos de opresión tanto en Palestina como en Brasil, la importancia de la solidaridad política entre los pueblos de Brasil

\footnotetext{
${ }^{1}$ Pós-doutoranda no Programa de Pós-Graduação em Filosofia da Universidade Federal de Santa Catarina (PPGFil UFSC). Membra pesquisadora do Laboratório de Ética Ambiental e Animal (LEA) da UFF e co-coordenadora do projeto Making Connections.

${ }^{2}$ Professor de Filosofia da Educação da Universidade Federal Fluminense. Membro permanente do Programa de PósGraduação em Bioética, Ética Aplicada e Saúde Coletiva (PPGBIOS-UFF) e do Programa de Pós-Graduação em Ensino (PPGEn-UFF). Coordenador do Laboratório de Ética Ambiental e Animal (LEA) e co-coordenador do projeto Making Connections.
} 
y Palestina y el papel de el boicot, además de denunciar la apropiación por parte de Israel de las causas LGBTQIA+ y animalistas.

Palabras claves: colonialismo; ocupación militar israelí; Palestina; opresión; BDS.

Maio de 2021 foi mais um mês marcado pelos ataques de Israel ao povo palestino, em especial residentes em Gaza, após manifestações contra despejos arbitrários no bairro de Sheik Jarrah, em Jerusalém. Diante da repercussão mundial dos fatos, porém marcada pelas narrativas hegemônicas, convidamos o palestino Baha Hilo e a brasileira Sandra Guimarães para nos concederem uma entrevista e fazerem chegar outras vozes e narrativas contra-hegemônicas. Essa iniciativa desencadeou uma série de outras possibilidades de atuação, quando decidimos, então, reunir essas atividades em torno de um projeto vinculado ao Laboratório de Ética Animal e Ambiental (LEA) da UFF, no qual somos ambos/as pesquisadores/as. Assim surgiu o Making Connections, projeto coordenado por nós cujo objetivo é colaborar com a disseminação das vozes palestinas, bem como inserir chaves-conceituais que promovam uma percepção mais apurada e crítica sobre as condições nas quais o Povo Palestino tem sido submetido nas últimas décadas. Para tanto, entendemos que a questão Palestina é caso paradigmático no atual cenário global, tendo em vista a correlação entre as opressões identificada por uma perspectiva de justiça social ecofeminista animalista. Nesse âmbito, surgiu a organização do presente dossiê temático da Diversitates, doqual a entrevista agora faz parte. A gravação do encontro online ocorreu no dia 4 de junho, em inglês, via Google Meet. A íntegra da entrevista no idioma original, com legendas em português, será publicada no canal do YouTube do LEA ${ }^{3}$; aqui se encontra a versão traduzida para o português e brevemente adaptada para uma leitura mais fluida.

\footnotetext{
${ }^{3}$ Acessar: https://www.youtube.com/c/lea-uff/
} 
[Daniela Rosendo - DR] Olá a todes, muito obrigada por estarem aqui. Meu nome é Daniela Rosendo, sou brasileira, filósofa e educadora - na verdade, uma educadora em direitos humanos e, também, sou ecofeminista. Estou muito feliz em estar aqui com meus amigos Baha, Sandra e Fabio, e iremos conduzir esta entrevista hoje. Iremos ouvir Baha e Sandra sobre a situação na Palestina, o que significa ser um/a palestino/a em território ocupado, e queremos, com essa entrevista, ouvir as pessoas de lá e que moraram lá. Dessa forma, podemos nos conectar com esta outra narrativa e ouvir o que vem acontecendo na Palestina há décadas. Então, agradeço novamente a todes que estão aqui. Estou muito feliz em encontrá-los. Peço que se apresentem, por favor. Sandra, poderia começar?

[Sandra Guimarães - SG] Então, eu primeiro. Obrigada pelo convite. Estou muito feliz em estar reunida aqui com meus amigos queridos do Brasil e da Palestina. Fazia tempo que não os via, é muito bom estar aqui com vocês. Sou Sandra Guimarães. Sou brasileira, mas tenho morado fora do Brasil por metade da minha vida agora. E tive a sorte de viver na Palestina por muitos anos. Me mudei para lá em 2008. Fui para lá pela primeira vez em 2007 e decidi me mudar para lá em 2008, onde vivi até 2013. Mas então, depois de ir embora, eu retornava todos os anos por três meses. E trabalhei lá no campo de refugiados de Aida, em Belém, no projeto de base de empoderamento de mulheres. E, depois que fui embora, iniciei grupos guiados de brasileiros/as na Palestina. Então, todo ano, eu voltava e era guia de um ou dois grupos em um tour político de solidariedade. E Baha era uma grande parte desse projeto. Ele me ajudou a organizá-lo e também foi guia em muitos lugares. Então isso, bem, o que mais posso dizer? Acho que já disse isso. Ah, 
certo. Sim. Então, eu sou uma militante de direitos humanos e animais. Estive ativa na última década fazendo atividades para alcançar, eu espero, liberação humana e animal. Então, Baha...

[Baha Hilo - BH] Obrigado, Sandra, obrigado, Daniela e prazer em conhecê-lo, Fabio. Meu nome é Baha; eu diria que uma das pessoas mais incríveis que conheci durante meu ativismo na Palestina definitivamente foi Sandra, que também é uma chef vegana, tipo, sim, foi mesmo como um dos presentes que o universo me deu. Certamente o agora e Sandra. Meu nome é Baha, nasci na cidade de Belém, em 1980. Tenho 41 anos de idade e, toda a minha vida, vivi sob opressão israelense. O objetivo de hoje é tentar explicar certos elementos, [como é] viver sob aquela administração brutal, e ajudar as pessoas a entender o que está acontecendo. Sim, Sandra mencionou que eu fui guia para muitas pessoas; trabalho como educador principalmente para estrangeiros/as que vêm visitar a Palestina, e os/as ajudo a entender a realidade que nos é imposta de um jeito que é fácil de entender. Claro, a presença na $\mathrm{Pa}-$ lestina é essencial. Como a iniciativa na qual eu trabalho - chamase "To Be There" - o que significa estar na Palestina, porque somente estando na Palestina você será capaz de entender a realidade, quando você a vê, a vive, a cheira, a prova, e você tem a oportunidade de nos conhecer do jeito que somos, em vez de, vamos dizer, sermos apresentados para o mundo através dos olhos de nosso opressor. Então, vamos torcer para que esta entrevista nos ajude, mesmo sendo impossível trazer a Palestina digitalmente, mas faremos o nosso melhor.

[Fabio A G Oliveria - FAGO] Olá, meu nome é Fabio Oliveira. É uma honra estar aqui com vocês hoje. Eu sou professor da Filosofia da Educação na Universidade Federal Fluminense e 
eu venho trabalhando com direitos humanos e direitos dos animais há mais de uma década. Tudo o que aprendi sobre a Palestina foram Sandra, Daniela e agora Baha que me ensinaram. Então é uma honra estar aqui com vocês e aprender mais e mais sobre aquilo que vocês estarão respondendo e explicando. Então, muito obrigado.

[DR] Muito obrigada. Eu tive o privilégio de visitar a Palestina com Sandra e Baha em 2015. Então tenho muitas saudades. Vamos fazer as perguntas agora. Fabio, poderia começar?

[FAGO] Sim, Daniela. Obrigado. A primeira pergunta que eu gostaria de fazer ao Baha é: o que significa viver sob território ocupado?

[BH] Bem, a resposta curta é que lhe negam suas liberdades básicas de expressão, de movimento, e tudo sobre todos os aspectos da sua vida é controlado pelo seu opressor. Isso significa todo aspecto, quero dizer, de uma coisa tão simples como beber água a algo que seria mais complicado, como viajar, onde você pode viver, onde você não pode viver, por onde você pode e não pode se movimentar, quanta comida, em alguns pontos, você pode comer porque, em certas partes da Palestina, nosso opressor conta as calorias da comida, quando eles permitem comida em certas partes da Palestina. Então é como viver sob o poder de um opressor que não te dá chances desde o dia em que você nasce até o dia em que você morre, simples assim. Eu tenho 41 anos de idade, e eu nunca tive um dia de liberdade na minha vida. Eu moro 15 minutos ao sul das terras santas de Jerusalém. E simplesmente porque eu nasci em uma família palestina na área ocupada de Belém, me é negado acesso ou liberdade de acesso àquele lugar. Tudo em sua vida requer permis- 
são dos israelenses, o que significa que você não tem direito a nenhum tipo de liberdade, mesmo quando eles dizem que vão te dar autorização. Essas autorizações significam que você deve se encaixar em critérios para poder se qualificar para isso. Então, o que significa viver sob ocupação militar ou sob os governos de Israel e Palestina? Significa que você é vigiado todo o tempo, desde o dia em que você nasce [quando] eles começam um arquivo para você na sua certidão de nascimento. E é assim que você será tratado desde o dia em que você nasce até o dia em que você é enterrado.

[DR] Obrigada, Baha. É muito difícil ouvir isso. E, é claro, muito mais difícil viver isso. Como turista lá, eu diria que é muito estranho e difícil ter essa liberdade de ir em território ocupado e sair e ver que você pode fazê-lo. Mas como visitante, como uma estrangeira, como turista, e sendo uma visitante política, nós entendemos o que significa estar lá porque estamos sob estas circunstâncias com vocês. E, por exemplo, durante a estadia no campo de Aida, ficamos sem água por alguns dias. Então podemos sentir o que significa, embora não nos sejam negados esses direitos. Eu gostaria de ir um pouco mais a fundo nessa questão para entender por que é um território ocupado. A mídia convencional geralmente afirma que isso [que] está acontecendo na Palestina hoje é um conflito antigo a respeito de religiões, terrorismo e perseguição unilateral contra judeus. Então eu gostaria que você nos contasse, por que isso não é correto [de ser afirmado]?

[BH] Por que não é correto? Simplesmente porque, se você entende a realidade do jeito que ela é, você fica furioso com o fato de que o governo brasileiro tem relações diplomáticas, ou econômicas, ou militares com um regime tão perverso. Você tem que ficar confuso a respeito disso, e isso é feito pela mídia convencional, por 
amigos, apoiadores, beneficiários ou defensores do estado de Israel. Então a confusão, por que há confusão sobre a realidade? Isto é algo que podemos perguntar a respeito de qualquer situação de opressão. Como, por exemplo, se olharmos para um lugar como a África do Sul durante o apartheid, nos anos 1970, o que ouviríamos? Ouviríamos que os europeus bonzinhos vieram para desenvolver a África do Sul, sabe, eles são pessoas bondosas, são legais. Eles querem trazer civilização para o sul da África. Então, você ouve uma narrativa muito positiva, do ponto de vista de quem está em cima. Mas quando as pessoas tiveram a oportunidade de ver e aprender sobre a realidade, do ponto de vista do oprimido, todo mundo enlouqueceu. E começaram a pedir pelo fim do regime, não pelo assassinato de pessoas brancas, mesmo que elas fossem superiores naquele contexto. Mas havia uma demanda para terminar uma situação em que alguns são superiores e outros inferiores, baseado em nascimento. Queria dizer uma coisa sobre a sua visita; [...] quando você veio para visitar a Palestina, você tinha um visto para Israel, certo? O que significa que você tinha exatamente os mesmos direitos que qualquer indivíduo judeu israelense. Quando eu fui ao Brasil com um visto, eu tinha menos direitos que os brasileiros. Eu lembro de quando estávamos no Rio, eu estava dizendo que eu gostaria de visitar a Favela da Maré, e eu ouvi pessoas que apoiavam - "sim, esta é uma parte de nossa vida que você tem que testemunhar" - e outras pessoas que diziam para não irmos. Mas o movimento deles em direção à Favela da Maré foi baseado na escolha deles, não em uma lei que te impede de ir lá. Agora, aqui, o que temos é uma situação em que tudo o que o Estado de Israel impõe é um reflexo da lei que o Estado de Israel faz. Vou dar um exemplo. A confusão a respeito de Israel-Palestina mostra que Israel tem uma geografia e a Palestina tem outra geografia. Certo? Mas Israel e Palestina são dois termos diferentes que usamos para exatamente a mesma geografia [...]. Então, Israel e Palestina, para 
muitas pessoas, são vistos ou presumidos como duas geografias separadas quando, na verdade, [...] são dois nomes separados para exatamente a mesma geografia. Você mostra o mapa da Palestina para o embaixador de Israel em Brasília, ele vai dizer "ah, este é um mapa de Israel". Você mostra o mapa de Israel para um palestino, ele dirá “ah, este é um mapa da Palestina”. Então, a partir desse ponto, se as pessoas presumirem que Israel e Palestina são duas geografias separadas, elas ficarão confusas a respeito de tudo o que vem a seguir. Certo? A geografia da Palestina é completamente controlada pelo governo israelense. Se você é um judeu israelense você vivencia o território ou a região do mesmo jeito que um brasileiro vivencia o Brasil. Mas se você fosse um palestino, nascido em uma família palestina, vivendo sob o regime do Estado de Israel, você teria uma experiência radicalmente diferente. Exatamente assim como se você fosse uma pessoa branca na África do Sul, você vivenciaria a geografia de uma forma radicalmente diferente de um sul-africano negro. Por quê? Porque um é, pela lei, superior, e o outro, inferior. Digamos, temos palestinos vivendo na cidade de Nazaré. Eles são sobreviventes de uma limpeza étnica na Palestina, executada pelos fundadores do Estado de Israel em 1947, 48 e 49 . O resultado da limpeza étnica foi o assassinato de quase 15 mil palestinos. E essa é a fundação do Estado de Israel, assassinando 15 mil palestinos, expulsando quase 750 mil de suas casas e propriedades, das cidades e vilas por toda Palestina. Estamos falando de quase 530 lugares. Poucos palestinos sobreviveram, estamos falando de $15 \%$ de toda a população palestina na época que sobreviveu, e os fundadores forçaram esses palestinos a viver sob um regime militar israelense. Veio 1966, e os israelenses aboliram o regime militar e o substituíram por um regime civil que mantém a inferioridade dos palestinos, até mesmo eliminando suas identidades - por exemplo, o Estado de Israel não chama os palestinos 
de palestinos. Ele os chama de árabes israelenses, a fim de desconectá-los de sua terra natal, como se um palestino vivendo em Nazaré não fosse palestino. Ele é um árabe israelense. Certo. Então ele não pertence a Nazaré, ele pertence a qualquer país que fala árabe, mas, definitivamente, não ao seu jardim, à sua casa, à sua família, ao seu legado. Certo? Este é um grupo de palestinos. Estes palestinos são completamente separados dos palestinos em Jerusalém, eles têm acesso uns aos outros, mas vivem sob um regime completamente diferente do que os palestinos em Jerusalém. Palestinos em Jerusalém, por lei, são chamados de residentes permanentes de Jerusalém. Eles não têm um Estado, não têm nacionalidade, estão lá porque o Estado de Israel permite que eles fiquem lá até serem removidos. E muitos desses palestinos são removidos diariamente. Se você ouve notícias sobre Sheik Jarrah ou sobre o Portão de Damasco, qualquer um, Silwan, qualquer vizinhança palestina... o problema nessas situações, são lugares nos quais o Estado de Israel inventou uma lei que criminaliza a existência destas famílias em seus lares. Então sua própria existência em casa se torna ilegal. E o que o Estado de Israel faz? Expulsa você de casa ou destrói sua casa, como as 17.600 casas que foram destruídas pelo Estado de Israel na cidade de Jerusalém. E uma coisa em comum entre todas essas pessoas é que elas são palestinas. O mesmo Estado que constrói casas para famílias judias em Jerusalém é exatamente o mesmo que destrói a sua casa. E uma vez que eles terminam de destruir a sua casa, eles te dão uma conta. Então você tem que pagar os gastos da destruição da sua casa. E então temos a terceira lei feita pelo Estado de Israel, mas aplicável aos palestinos em Gaza. Dois milhões, 2.2 milhões de pessoas, sabe, todas elas desde que nascem são residentes de um território hostil, o que significa que todos os palestinos que foram assassinados em Gaza, desde 1967 até hoje, incluindo o início [do] mês de maio [...]. To- 
das essas pessoas foram assassinadas dentro da lei israelense, nenhum criminoso israelense que matou uma criança palestina, um pai palestino, uma mãe palestina em Gaza, nenhum infringiu a lei, nenhum! Porque está dentro da lei assassinar palestinos se você está usando um uniforme, você não tem que lidar com as consequências de explodir uma família ou explodir um prédio de 56 apartamentos, deixando 56 famílias sem casa, simples assim, isso é seguir a lei israelense. E aí temos um quarto conjunto de leis aplicadas aos palestinos na Cisjordânia ocupada. É um regime militar feito de mais de 1.660 ordens militares. Através dessas ordens militares, o Estado de Israel confiscou 1/3 das propriedades dos residentes da Cisjordânia, que você chamaria de território ocupado. $\mathrm{O}$ exército israelense utiliza aquela propriedade por, em média, um dia a cada três meses; o objetivo não é confiscar a propriedade da sua família, porque precisam dela por razões de segurança. Não, são quatro dias por ano, a intenção é impedir que você e sua família tenham acesso à sua propriedade. O Estado de Israel destruiu mais de 40 mil casas de palestinos e ocupou a Cisjordânia no passado, durante seu controle de território. Exatamente o mesmo governo que constrói casas para judeus israelenses, quase 750 mil delas entregues na Cisjordânia ocupada, exatamente o mesmo governo ia por aí destruindo mais de 48 mil casas de palestinos. O mesmo governo que destrói e põe bloqueio nas estradas de entrada e saída das nossas comunidades por todo o território da Cisjordânia - temos mais de 600 pontos onde o exército israelense pode simplesmente colocar um posto de controle para assediar as pessoas, assassinando pessoas nesses postos, impedindo mulheres grávidas de irem ao hospital porque o soldado acha legal impedir que a ambulância passe. Perdemos tantos bebês recém nascidos nestes postos de controle militares. Exatamente o mesmo governo que coloca postos de controle no nosso caminho destrói nossas propriedades 
para construir estradas que ligam comunidades ou ocupações exclusivamente judias por toda Cisjordânia, junto com o Estado de Israel. Então, nós temos judeus israelenses que moram a até cinco milhas de onde eu estou e falo com vocês agora. O jeito que eles usam [as estradas] é radicalmente diferente do jeito que eu uso. A vida que eles vivem é radicalmente diferente da vida que me é forçada. E vivemos em uma área a cinco quilômetros quadrados uns dos outros. E mais do que isso, você terá controle sobre recursos hídricos, sobre movimentação, assassinatos que acontecem diariamente, às vezes semanalmente, mas assassinatos de palestinos acontecem, prisão de palestinos. É legalmente permitido para o Estado de Israel prender um palestino de 14 anos e levá-lo a um centro de detenção para adultos, sentenciar um palestino de 14 anos em um tribunal militar israelense. Porque, por lei, um residente palestino da Cisjordânia é tratado como um adulto a partir dos 14 anos, um judeu israelense vivendo na Cisjordânia, ele é um adulto aos 18 anos de idade. Por que é diferente? As pessoas dizem, “ah, é lei militar e lei civil'? Bem, não, se eles quiserem destruir sua identidade, destruir seu futuro, destruir sua mente, eles têm que te amedrontar para que você não infrinja leis militares a partir dessa idade, e Israel diz "não, não temos crianças presas". E eles estão certos! Estão certos porque um palestino não é mais criança a partir dos 14 anos, ele é um adulto. Então o Estado de Israel tem esses quatro sistemas - sistemas legais separados, impostos sobre o povo palestino que vive no território que chamamos de Palestina e no território que eles chamam de Israel. Temos quatro leis separadas; uma lei para os que nascem em famílias judias [e] quatro leis para os que nascem em famílias palestinas, e nessas quatro leis, o Estado de Israel mantém a dominação de um grupo de pessoas sobre outro, o palestino. Agora, quando o regime que controla qualquer geografia no planeta, quando o regime vigente cria um sistema de dominação de um grupo de pessoas sobre outro por motivo de nascença. 
Sabe, por uma razão, é claro, de raça, etnia, língua, cor da pele, o que for, existem categorias diferentes. E em nossa situação é pelo motivo de fé e nacionalidade. Se qualquer regime no planeta cria um sistema de dominação de um grupo sobre outro, quer dizer que este regime está cometendo o crime de apartheid. Sim, o último país que cometeu o crime de apartheid foi a África do Sul, mas não foi o último no mundo. Porque há um regime que mantém a dominação de um grupo de pessoas, judeus israelenses, sobre outro grupo, palestinos. Mas não só de um jeito, [senão] de quatro jeitos diferentes. Muita gente vem da África do Sul nos visitar e eles dizem coisas como "onde você vive é mais complicado, mais brutal e mais perverso do que aquilo ao que nós tivemos que sobreviver". E o motivo disso é muito óbvio. O Estado de Israel criou um espaço minúsculo de 27 mil quilômetros quadrados, a Palestina é desse tamanho, não é tão grande quanto a África do Sul. Não é como colocar alguns milhares de palestinos no Brasil. É uma área muito pequena que o Estado de Israel controla - controla a região e controla as pessoas aqui. Como eles podem fazer algo mais complicado que a África do Sul e sair impunes? Muito simples. Eles fazem porque o território é pequeno, eles têm controle absoluto das fronteiras, o que quer que seja que entre ou saia. Quando a Sandra veio para cá, quando a Daniela veio para cá, elas tiveram que vir com um visto de Israel, agora como um visto para a Palestina. E se os israelenses soubessem das intenções delas, que elas viriam para visitar uma comunidade palestina, o acesso delas provavelmente seria negado. Quando produtos vêm, para as pessoas, tudo tem que ser aprovado pelo Estado de Israel. O Estado de Israel tem controle absoluto de cada entrada do território, através disso eles podem nos separar uns dos outros, tipo, a cidade de Gaza que está a 40 minutos de carro de mim, e eu nunca tive acesso a Gaza. Lembrem-se, eu tenho 41 anos de idade, sabe, Jerusalém, sem liberdade de acesso, eu tenho que me esgueirar para entrar em Jerusalém. Como isso é 
possível? É possível porque eles têm controle absoluto da geografia. Segunda coisa, como eles sabem [quem é o oprimido] no apartheid da África do Sul? Eles sabem por causa da cor da pele. Quando você mora aqui, você sabe que muçulmanos, judeus, drusos, samaritanos, qualquer fé que temos aqui na Palestina, todos nós somos parecidos e diferentes. É um lugar muito, muito diverso em termos de fé, etnia, religião e cor da pele. Então como você pode, como o soldado pode saber quem é palestino, quem ele pode maltratar? É muito fácil. Nós estamos no registro de nascimento deles desde o dia em que nascemos. No dia em que você nasce, o Estado de Israel decide, você vai ser maltratado do jeito que palestinos de Nazaré são maltratados? Você vai ser maltratado do jeito que palestinos em Jerusalém são maltratados? Você vai ser maltratado do jeito que palestinos na Cisjordânia são maltratados, ou do jeito que os palestinos em Gaza? Isso é decidido pelo Estado de Israel no dia em que você nasce. Não é algo decidido com base em seu comportamento. É por isso que a opressão israelense sobre a sua vida não é relevante ou relacionada ao seu comportamento. Você pode ser um palestino que serve o exército israelense, temos alguns desses. E você pode ser um palestino que carrega armas para lutar contra o exército israelense. Temos alguns desses, além de todos entre as duas coisas. Todos são oprimidos, todos são dominados e tidos como inferiores por lei pelos judeus israelenses. Essa é a realidade do jeito que é, não é confuso. Para nós, pelo menos, não é confuso. É muito, muito simples porque nós somos os oprimidos no sistema, mas o jeito que somos oprimidos é traduzido e vendido lá fora. Nós não temos o mesmo tipo de tecnologia de comunicação, orçamento para relações públicas e máquina de propaganda para confundir o mundo. Não temos isso. Sabe quem precisa de propaganda? O opressor. Quem precisa dar uma imagem positiva? O opressor. Quem precisa confundi-lo sobre certo e errado? O opressor. Quem precisa se mostrar como vítima? O opressor! 
Sabe? Por que sul-africanos foram as vítimas dos negros? Os aborígenes foram as vítimas do [...] os aborígenes foram os monstros do deserto, sabe, na Austrália, a população aborígene mal se qualificava como humana, lá por 1966, antes de $1966 . .$. eles eram considerados animais pela lei, eles enquadravam-se sob as leis da fauna e da flora, e o quê? Algo assim, eu não sei. A lei da flora e a fauna considerava a população nativa da Austrália animais. Agora, quem precisa fazer isso? O opressor. Sabe? Antes de nós, não estávamos oprimindo ninguém, conhecíamos essa igualdade. Acreditamos que todos nascem livres e iguais desde o nascimento. Então, quem é livre e igual? Definitivamente não a gente. Então, não é tão confuso. Enquanto olharmos para Israel e Palestina do ponto de vista do opressor, do superior, do beneficiário, sim, você ficaria confuso com isso. Bem, se olharmos para a Palestina do ponto de vista do oprimido, então não, não há confusão no assunto. Claro que falei bastante.

[FAGO] Muito obrigado, Baha, por essa resposta clara, profunda e importante, especialmente para mim, alguém que nunca esteve na Palestina ainda. E, baseado no que você disse, eu gostaria de perguntar algo para a Sandra, que é uma mulher brasileira que teve a oportunidade de viver na Palestina. $E$ acho que esse é um aspecto muito importante para nossos/as espectadores/as também, que, como eu, não tiveram a chance de visitar a Palestina ainda. Então, gostaria de perguntar a você, Sandra, por que você acha que nós como indivíduos, mas também as instituições e movimentos sociais, organizações no Brasil e outros países devemos nos importar e apoiar a Palestina?

[SG] Então, a resposta é longa e, ao mesmo tempo, muito simples. Nas últimas semanas me perguntaram muito a seguinte questão: 
por que brasileiros/as deveriam se importar? E sempre, sempre me surpreende que as pessoas precisem de uma justificativa para demonstrar solidariedade política. Acho que, para mim, nem é preciso dizer que estamos do lado do povo oprimido que resiste. $\mathrm{E}$ como Baha acabou de dizer, eles estão resistindo a um sistema brutal que os nega os direitos mais fundamentais, os direitos mais básicos como o direito à vida. E ainda assim, as pessoas precisam ser convencidas de que elas deveriam demonstrar apoio, que elas deveriam ser solidárias, demonstrar solidariedade. E é muito triste porque, sabe, Baha acabou de dizer algo que me tocou em um nível muito profundo, porque muitas pessoas no Brasil, eu acho, podem se identificar com isso. Ele diz que a opressão dos/as palestinos/as não é baseada em seu comportamento. Não existe algo como um palestino bom para os colonizadores. Então quando as pessoas colocam essas culpas nos palestinos, como "vocês deveriam se comportar melhor para que não sejam bombardeados, para que não sejam mortos", "se você morreu, deve ter feito algo ruim", realmente nos leva de volta ao Brasil, e o mesmo discurso que é usado contra pessoas pobres e negras. Sabe, se negros/as são mortos nas favelas, ou em qualquer lugar do Brasil, essa pessoa deve ter feito algo errado. E assim como os palestinos oprimidos, pessoas oprimidas em todos os lugares do mundo têm que provar que eles merecem o direito básico à vida. Apenas viver, não é algo dado a eles, eles têm que provar que merecem. E a situação padrão é que eles fizeram algo errado. E nós realmente temos essa fantasia de que se você se comportar bem, você sabe, então o Estado não irá matá-lo. Se você se comportasse melhor, os colonizadores não tomariam sua casa, o que absolutamente não é verdade. Eu lembrei de algo. Acho que ano passado essa menina, acho que de sete anos, Ágatha, a menininha no Rio que foi morta dentro de uma van voltando da festa de aniversário de sua prima. Ela levou tiros nas costas da polícia brasileira. E eu lembro que seu avô deu uma entrevista para a televisão 
brasileira dizendo "mas sabe, ela era uma aluna tão boa, tinha notas boas, estava fazendo aulas de balé". E o que esse homem estava dizendo é que ela se comportava bem. Ela era boa, ela não traficava, não vendia drogas. Ela era apenas... nós fizemos tudo o que vocês nos disseram para fazer para sermos bons cidadãos. E ainda assim, ela foi morta. E é a mesma coisa na Palestina. Então, para voltar para o porquê que as pessoas no Brasil, vamos focar no Brasil, deveriam mostrar solidariedade à causa palestina: é porque nós somos cúmplices disso. O governo brasileiro tem laços militares muito fortes com governos israelenses. As armas matando pessoas nas favelas foram compradas de Israel, e foram testadas nos palestinos. Então quando tanques invadem favelas no Rio, o topo do tanque foi comprado de Israel e testado em palestinos. E a segunda coisa é que Israel é mestre em controlar civis. Então o inimigo é interno, certo? Para Israel, os inimigos são os palestinos. E é a mesma mentalidade que aplicamos no Brasil, quando você declara guerra às drogas. Então em Israel é a guerra contra o terrorismo e no Brasil a guerra às drogas. $\mathrm{O}$ inimigo é parte da população. $\mathrm{E}$ utilizamos os mesmos métodos de controle da população civil no Brasil. Os mesmos. As mesmas armas, a polícia no Brasil é treinada por militares e Israel, de Israel, eles vão lá e treinam a polícia porque eles são muito bons em controlar civis. E assim podemos fazer a mesma coisa dentro do Brasil. E a terceira coisa é que o controle da população civil na Palestina foi desenvolvido por Israel, e agora eles podem vendê-lo em qualquer lugar. No Brasil, somos um pouco obcecados com segurança privada e essas coisas, a tecnologia que você vê em condomínios, por exemplo, são compradas de Israel. Empresas israelenses [estão] vindo, e após oprimirem os palestinos por décadas e controlar a geografia e a movimentação das pessoas, elas vendem ao Brasil e isso é usado mesmo nos prédios civis, como os condomínios. Eu lembro, dois anos atrás eu estava no Brasil, na minha cidade, Natal, ouvindo rádio. E havia 
uma propaganda para uma empresa de segurança que fazia câmeras de segurança, arame farpado, toda essa tecnologia para tornar os lugares seguros. E eu quase caí da minha cadeira, porque a voz na propaganda de rádio disse "tecnologia israelense, tecnologia de guerra", você pode confiar na gente porque temos tecnologia israelense. Para eles era uma ferramenta de marketing dizer, sabe, é israelense, sabemos que funciona. Então você pode confiar em nós, que nós faremos a segurança de seu condomínio. Eu acho que essas duas coisas, perceber que o governo brasileiro é cúmplice na opressão de palestinos ao comprar armas e usar essa opressão, tecnologia, e então usar contra nosso povo. Acho que se tem um país que deveria ser solidário, deveria demonstrar solidariedade à Palestina, é o Brasil, porque nós entendemos a opressão sob a qual eles vivem. É a mesma sob a qual as pessoas no Brasil também estão. Podemos não mandar US\$ 3.8 bilhões por ano para a indústria militar de Israel como os Estados Unidos fazem. Mas temos um grande papel na perpetuação da opressão do povo palestino.

[DR] Muito obrigada, Sandra. Vocês dois levantaram uma questão bem importante, que é como tudo está conectado. Existe essa mesma lógica de opressão e dominação acontecendo. Quando Baha explica o que acontece lá e Sandra traz o que acontece aqui, podemos dizer que é a mesma coisa. É a mesma lógica de dominação e criação de um inimigo contra o qual temos que lutar. Eu diria, eu acrescentaria que, respondendo por que deveríamos nos importar - é uma questão de justiça. É disso que estamos falando. É uma questão de justiça. E nós, como feministas, estamos sempre dizendo, chamando a atenção para dizer que mulheres são agredidas, e não culpadas da agressão. $O$ agressor é o culpado e aqui é a mesma coisa, como culpar a vítima, culpando o oprimido. É a mesma lógica novamente. São tipos diferentes de opressão, e trazendo isso, 
eu gostaria de direcionar outra pergunta ao Baha. Você já falou um pouco a respeito, mas pode acrescentar qualquer outra coisa. Falando sobre opressão, acadêmicos/as já identificaram que opressões têm faces diferentes [...] e funcionam em formas diferentes de subordinação e exploração, por exemplo, e da mesma maneira, como o capitalismo, colonialismo vem mudando o jeito de oprimir. Gostaria de perguntar como você entende e explica essa dinâmica de opressão perpetuada por Israel contra palestinos/as?

[BH] Sim, eu gostaria de seguir os comentários da Sandra, talvez de uma forma bem fácil e simples; solidariedade com o oprimido, dominado, abusado nada mais é que uma questão de decência. Se você é solidário com os sem-teto, não é porque você odeia a empresa ou o sistema que os fez sem-teto, é porque você é uma pessoa decente. É isso, basicamente. É uma questão de decência. Agora, transferindo. Transferindo aquela solidariedade para resistência é uma questão diferente, certo? As pessoas têm a obrigação moral de se posicionar contra opressão onde quer que elas a encontrem, da melhor forma que julguem necessário. Então sim, não é nada além de uma questão de decência. Agora voltando à sua questão. Como expliquei, regimes opressores que são criados pelo mesmo sistema são diferentes, como a Palestina que eu vivencio é muito diferente da Palestina que um palestino em Jerusalém está vivenciando, porque os sistemas de opressão são diferentes. Então, quando estamos falando sobre, digamos, as dinâmicas da opressão, elas têm que ser diferentes. As dinâmicas de aplicar a lei sobre nós em Gaza, sobre nós na Cisjordânia ocupada, ou sobre nós em Jerusalém, ou Nazaré, ou Umm Alfahem ou Al Lodd, as dinâmicas são diferentes. As técnicas são diferentes, mas elas servem exatamente ao mesmo propósito. Agora, o propósito, se você lesse qualquer coisa sobre a 
história da Palestina nos últimos 100 anos, você saberia que os fundadores do Estado de Israel queriam uma terra sem pessoas para pessoas sem terra, você sabe, já que isso é algo que vem de tão cedo quanto o início do século XX, mais de 120 anos atrás. Uma terra sem pessoas para pessoas sem terra. Agora a terra tem pessoas! O que fazer com elas? Retirá-las, retirá-las. Sabe? Sessenta e sete por cento de toda a população palestina não vive na propriedade da família, não vive em casa. São pessoas deslocadas, refugiados, deslocadas internamente e assim vai. A segunda coisa em comum entre todos nós como palestinos é que nossa terra ou foi completamente roubada pelos fundadores do Estado de Israel, ou parcialmente, então a diferença entre um palestino morando na cidade de Belém, a cidade antiga bíblica de Belém, e um palestino que mora, digamos, na cidade de Deir Yassin, não muito longe daqui, é que os residentes de Deir Yassin perderam todas as suas propriedades. Os residentes de Belém perderam quase $40 \%$ de suas propriedades, então não a terra inteira. Então, ou você perde a terra inteira ou parte dela. Isso é uma coisa comum entre todas as famílias palestinas no mundo hoje. Ter os seus significados roubados pelo governo de Israel, sabe; não é como se o governo israelense tivesse roubado e fugido para a Europa, não, eles apenas te negaram acesso. Então, as coisas nas quais devemos nos focar são os resultados da opressão israelense, mesmo que isso soe complicado, mas os resultados da opressão israelense são o deslocamento de palestinos, a remoção de palestinos, dando a impressão para as pessoas de que Israel tem uma minoria palestina, mesmo com o fato de que existem quase 8 milhões de palestinos vivendo sob controle direto do Estado de Israel. Nós somos a maioria de pessoas que é controlada e dominada pelo Estado de Israel. Mas a impressão de que somos uma minoria é uma impressão que tem a ver comigo, com a máquina de propaganda de Israel. E a dinâmica, eu digo isso o tempo todo - me diga um tipo de opressão, e eu lhe digo como o 
Estado de Israel a pratica. Você mencionou exploração; em qualquer cenário colonial, o opressor reduz o oprimido ao nível de dependência dele a fim de sobreviver. Isso aconteceu na África do Sul, aconteceu na escravidão, acontece com mulheres, acontece em quase todo... isso definitivamente aconteceu no Brasil nos últimos 400 anos, quando o oprimido é reduzido ao nível de dependência do opressor para sobreviver. Então, quando falamos sobre exploração, nesta forma, estamos falando sobre as centenas de milhares de palestinos que têm que passar por pontos de controle militar para chegar em uma área israelense de construção na Palestina, ou a uma fazenda israelense na Palestina, ou em uma zona industrial israelense na Palestina, onde eles são pagos menos do que qualquer trabalho médio, sem nenhum direito. Nós tivemos muitos palestinos que foram mortos em obras, da mesma maneira que muitas pessoas negras morriam nas minas. É só outro oprimido que está morto, você sabe, deixe a família enterrá-lo, sem nenhum tipo de direito, nenhum seguro. Talvez os israelenses tratem o palestino que não está sendo explorado de uma maneira que é melhor financeiramente do que o palestino que está trabalhado em uma obra na Cisjordânia, talvez, porque os padrões de vida entre os judeus israelenses são muito mais altos. Estamos falando de uma renda média para palestinos na Cisjordânia de quase 600 dólares. Estamos falando de 2.400 dólares para judeus israelenses em Israel, sabe, então mesmo que o israelense pague a você mil ou 1.500 dólares, ainda é mais baixo. E você custa muito menos a eles do que ter que contratar um judeu israelense. A segunda coisa é que, para exploração, quem nós exploramos? Não exploramos médicos. Não exploramos engenheiros. Não exploramos pessoas em tecnologia. Porque essas são pessoas instruídas. Quem nós exploramos? Explore o pobre, o não-educado, a mão-de-obra desqualificada e você tem isso sendo aperfeiçoado pelo Estado de Israel. Isso é apenas quando se trata de exploração. Diga outra forma de opressão, eu 
lhe direi como se aplica. Assassinato foi algo mencionado. Restringir movimentação é algo mencionado. Controle sobre a água, onde um palestino tem acesso a 65 litros de água por pessoa diariamente, o que é quase 45 litros a menos do recomendado por órgãos internacionais como a Organização Mundial de Saúde. E não muito longe da gente você tem israelenses vivendo em comunidades ou colônias exclusivas para judeus, onde eles têm acesso a 350 litros de água por dia, por pessoa. Exatamente o mesmo recurso. Nós sabemos que a água pode ser usada como arma. Sabemos disso porque não estamos muito longe de uma civilização que foi eliminada há cerca de 2 mil anos atrás somente cortando o abastecimento de água. A civilização Nabateia, eles que construíram Petra, que é como um ídolo no planeta. Como os romanos eliminaram aquela civilização? Eles cortaram o fornecimento de água, fizeram isso por quase 60 dias, não por 17 anos, mais de 2 milhões de palestinos vivendo em Gaza. Três por cento da água não está contaminada. Por 17 anos! É um milagre que palestinos em Gaza ainda existam [dadas] as condições que foram criadas pelo Estado de Israel sobre os palestinos em Gaza. Um relatório saiu em 2018 dizendo que Gaza, no ano 2020, não seria adequada para humanos, para a existência humana. Deveria ficar inabitada, seria inabitada até 2020 para seres humanos; este é um relatório que eles publicaram em 2018. Então, quando Israel bombardeou Gaza em 2021, em maio, eles bombardearam um lugar que eles já tinham tornado inabitável para seres humanos. Então eu posso te contar porque Israel tem quatro sistemas separados de opressão, dominação e apartheid sobre os palestinos, esses quatro sistemas criam formas de opressão inimagináveis, mesmo, sabe, vou te contar. Eu desafio as pessoas, às vezes. Eu peço a eles que digam, e eu conto a eles como o Estado de Israel pratica isso. Me traga um exemplo de opressão que você conhece e eu te digo como o Estado de Israel o 
aplica, em qual comunidade da Palestina, em que canto da Palestina, e talvez eu não te direi os nomes das vítimas porque, imagine, é impossível lembrar, algo como 150 mil nomes palestinos foram assassinados, é impossível. Nós temos apenas uma estimativa de quantas pessoas foram mortas sob o regime de Israel nos últimos 73 anos. É uma estimativa que fica entre 150 mil e 200 mil pessoas. Vítimas racializadas são uma estimativa, as vítimas brancas nós conhecemos, podemos nomeá-los se quisermos. Mas vá em frente, me dê um exemplo de uma forma de opressão. Eu aprendi muito sobre opressão no Brasil; Daniela e Sandra, vocês me levaram para o Brasil e me apresentaram ao Brasil do mesmo jeito que eu apresentei a Palestina a vocês. Eu tenho visto formas de opressão que não são chocantes, porque é parte do dia a dia em nossa vida aqui. Mas o que me chocou foi que essas práticas estão sendo executadas por um governo contra seus próprios civis, seu próprio povo. Quando eu visitei algumas das comunidades indígenas, vendo sua terra natal, seus solos sagrados estão sendo destruídos em Brasília para construir uma rodovia. Sabe, essa é a história de quase 1200 quilômetros de estradas que o Estado de Israel pavimentou ao nosso redor na terra de palestinos indígenas. Nós precisamos nos comprometer com as favelas. Isso é apenas um aspecto aqui. Quando você me apresenta para o MST, por exemplo, claro, os motivos no Brasil podem ser um pouco diferentes porque é um governo oprimindo seu próprio povo. Sabe, aqui é um governo que quer se livrar das populações indígenas da Palestina. Então, me diga uma opressão, uma forma de opressão, e eu te direi como o Estado de Israel a aplica.

[FAGO] Muito obrigado, Baha. Sua resposta nos ajuda muito, não só para entender como o ativismo deve agir, mas também para nos ajudar, como acadêmicos/as, a pensar em ferramen- 
tas analíticas para entender melhor como a opressão está ligada a diferentes maneiras para fazer acontecer na vida cotidiana das pessoas de diferentes povos. Gostaria de me referir a algo que você, Baha, apontou. $\mathrm{O}$ direito à terra. $\mathrm{E}$ perguntar à Sandra, se eu puder, algo relacionado a isso. Sabemos que é comum a todas as pessoas expostas a essas diferentes formas de dominação e opressão, como Baha falou, que envolvem exploração, marginalização e outros tipos de violência, lutar pelo direito à terra. No Brasil, temos movimentos organizados, como o MST. O Movimento Sem Terra, que vem lutando pela reforma agrária, e pelos direitos à terra, que também incluem o direito à autonomia alimentar e segurança nutricional. Também sabemos que em situações de opressão, essas pessoas têm seus direitos básicos negados. Isso ocorre no Brasil, que voltou ao mapa da fome durante o governo Bolsonaro, e na Palestina, devido aos constantes ataques de Israel. Brasileiros/as e palestinos/as empobrecidos/as sob ataque vivem em uma situação constate de insegurança alimentar e hídrica, e desnutrição crônica. Você poderia falar um pouco sobre a conexão entre esses aspectos e o sistema de opressão, os quatro sistemas de opressão que Baha nos explicou? Obrigada.

[SG] Antes de responder, eu gostaria de dizer algo a respeito do que Baha disse: que pode parecer diferente, Baha, no nosso caso, porque você disse que é o governo que opera esses sistemas opressores contra seu próprio povo. Eles ainda são colonizadores, podem não ser os primeiros. Eles podem ficar lá por um tempo, mas estão apenas levando adiante um plano de colonização. Então, é a mesma história nesse sentido, porque eles continuam o trabalho que colonizadores da Europa começaram, que os primeiros colonizadores começaram há 500 anos. Mas o plano é o mesmo. A mentalidade é a mesma. E, se você perguntar a comunidades indígenas, 
elas diriam: "olha, é assim mesmo". Eu tenho um amigo que viveu por muito tempo na região amazônica e toda a vez que eu contava algo sobre a Palestina a ela, ela me dizia: "mas olha, vá até a região amazônica. A Palestina é aqui também, é a mesma coisa". Então isso se conecta muito bem com a questão da terra. Então, Baha mencionou brevemente que existe contagem de calorias em Gaza. E eu gostaria de falar um pouco mais sobre isso, porque eu acho que realmente mostra a extensão desse plano de genocídio, tudo... todos os aspectos disso são planejados, nada fica de fora, sabe... existe um plano por trás de tudo. E eu lembro de ainda estar vivendo na Palestina em 2012 quando esse relatório veio, do Ministério da Defesa, na verdade, uma organização israelense encontrou arquivos do Ministério da Defesa dizendo que há pessoas no governo israelense calculando quantas calorias podem entrar em Gaza por pessoa, apenas para que as pessoas não morram de fome - mas também [para que] não sejam saudáveis. Então eles inventaram esse número, 2.279 calorias por pessoa diariamente, e então eles traduzem isso para quantos caminhões de comida poderão entrar em Gaza. É tão cruel que eles foram ainda mais longe e pensaram em como fazer com que essas calorias venham de comida ruim, não lentilha e comida nutritiva, mas comida processada, sabe, açúcar, esse tipo de coisa, para realmente enfraquecer a saúde, para que eles fiquem vivos, não morram de fome, mas pouco a pouco, a saúde deteriore eles acabem morrendo disso. E vemos a mesma coisa, não com essa dimensão, claro, em muitas comunidades empobrecidas no Brasil, onde as pessoas estão morrendo por algo que chamamos, em português, de "nutricídio", que seria algo como um genocídio pela nutrição, eu chamaria de "nutricide" se fôssemos inventar uma palavra em inglês. Não sei se usam essa palavra. Então, também há um plano de dar comidas de baixo valor nutricional para pessoas pobres, negros, pardos, comunidades indígenas, para que eles não tenham acesso à comida de qualidade. 
E pouco a pouco, toda a doença conectada a essa dieta de processados e comida ruim irá levá-los a uma situação de saúde muito ruim. Então volta-se à terra. O que está acontecendo na Palestina, o que vem acontecendo nas últimas décadas é o que está acontecendo no Brasil, no sentido de que agricultores são negados acesso à terra. Então eles não podem cultivar a terra, não podem plantar sua comida, não podem plantar a comida que faz sentido para eles, o jeito tradicional deles de se alimentar, porque Israel está confiscando todos os seus recursos, não só a terra, mas a água, como Baha disse. Então se você for um agricultor palestino, você tem seu acesso à água negado, seu acesso à terra negado, você não pode fazer sua própria comida. Com isso, se torna impossível que os palestinos tenham soberania e mesmo autonomia alimentar neste momento. Por outro lado, vemos cada vez mais comida processada entrando no mercado palestino. Aí você vê a substituição da dieta tradicional palestina, que é a dieta mediterrânea, extremamente saudável, com muitos vegetais, pouca proteína animal, muitas gorduras boas como óleo de oliva, azeitonas, amêndoas, tudo isso, por comida processada. E, novamente, vemos o mesmo. Trabalhei no campo de Aida e podia ver os mesmos problemas ligados a esses hábitos alimentares que estão mudando, que eu vejo em comunidades empobrecidas no Brasil. A propósito, vamos falar um pouco sobre essa merda de veganwashing, porque também está conectado a isso. Pessoas viam em Israel um paraíso vegano, o império vegano. Mas o que eles não percebem é que Israel confiscou terras dos palestinos onde estes costumavam plantar comida, e eles puseram granjas de galinhas, porque Israel é o maior consumidor de aves no mundo - se você calcular o número de habitantes e os quilos de aves que eles comem - eles estão negando comida à base de plantas aos palestinos, a dieta tradicional deles, para colocar granjas de galinhas lá, pegar toda a água, sujar a terra, e comer essa 
quantidade enorme de animais, e então reivindicar o império vegano, dizer que eles são o paraíso vegano. Vejam só! É... sim. E então o terceiro aspecto disso. A primeira coisa seria negar aos palestinos acesso à terra e à água para que eles não possam plantar comida, e então bombardear o mercado com essas comidas altamente processadas, e os palestinos teriam poucas opções a não ser comprá-las, e aí o terceiro aspecto é que eles não podem... isso é algo que todos os colonizadores fazem... eles se apropriam de tudo o que eles não conseguem destruir, tomam para si. Eles não conseguiram destruir a herança culinária extremamente rica da Palestina. Então agora, é israelense. Agora hummus é israelense. Falafel é israelense. E eu já vi... eu estou na Europa, em Paris, [que] há muitos restaurantes israelenses que, quando você abre o cardápio, é comida palestina que está sendo vendida. Eu vivi em Berlim também, e todos os restaurantes israelenses lá vendiam hummus e falafel, ao ponto de muitas pessoas no mundo acharem que hummus é um prato israelense. Elas esquecem que Israel foi criada em 1948 e pessoas nessa região vêm comendo hummus e falafel há muito mais tempo do que isso. Então, voltando ao Brasil, de novo, a mesma luta, família palestina, agricultura... perdão, agricultura familiar brasileira, uma situação muito difícil, porque você vê pequenas fazendas familiares, onde eles plantam a maioria da comida que comemos no Brasil; 70\% da comida que brasileiros comem são plantadas em pequenas fazendas, fazendas familiares, e então isso é substituído por essa enorme monocultura e exploração animal também. É a mesma coisa. Veja, de qualquer forma que você olhe, você consegue traçar paralelos. E eu lembro das muitas vezes que eu guiei grupos, grupos brasileiros lá, e as pessoas diziam “ah, é que nem está acontecendo no Brasil”. Eu vi isso lá, é a mesma coisa. Eu acho que a luta pela terra - e porque ainda estamos lutando contra a colonização no Brasil, a região amazônica ainda está 
sendo colonizada, você sabe, a mesma... você tem populações indígenas nativas sofrendo genocídio, sendo completamente deslocadas ou mortas, de um jeito direto ou indireto, para deixar a terra para uma monocultura enorme ou pecuária. Não dá para não traçar paralelos, eu acho.

[DR] Sandra, muito obrigada por trazer [essa questão das] corporações que trabalham com governos e Estados que estão perpetuando a colonização aqui e no resto do mundo. Nós estamos chegando ao fim de nossa conversa aqui, e eu gostaria de pedir a vocês dois agora, Sandra e Baha, que digam algumas palavras sobre como as pessoas ao redor do mundo podem ajudar a Palestina. Baha, você poderia começar?

[BH] Certo, primeiro as damas, então eu começo. Deixe-me dizer algo rapidamente, Sandra. A coisa que eu levei para a Palestina quando voltei do Brasil foi um medo extraordinário. Porque o que eu vi na Palestina e o que vi no Brasil, poderia ser a Palestina em 500 anos. Sabe, eu vi a exploração, vai a fundo na mentalidade a ponto de um bom amigo meu, de Aracaju, ele queria me levar para a quarta cidade mais velha do Brasil. E, você sabe, aqui a quarta mais velha tem cerca de 6 mil anos. Mas ele me levou a uma cidade de 400 anos e eu vi uma cidade portuguesa lá. E está tão arraigado, mesmo para intelectuais, que não questionam essas coisas, que não entendem que vivemos em solo indígena. É como um palestino daqui a 500 anos acreditando estar provavelmente vivendo em um lugar colonizado em vez de estar vivendo em casa. Então, sim, eu vim para casa com esse medo, e muitas pessoas dizem que não, isso não vai acontecer, mas há 400 anos as pessoas no Brasil também não teriam acreditado que isso aconteceria, sabe, e a diferença entre um colonizador e um indígena é que o colonizador sempre 
irá ver uma oportunidade para exploração. E é isso que está acontecendo na Palestina, quando você vem à Palestina, agora, ela está muito, muito diferente. Parece, vocês estiveram aqui e sabem que se você aterrissa em Tel Aviv, você está chegando em uma cidade europeia; estamos muito longe da Europa, não tanto quanto o Brasil. Não estamos na Europa. Sabe, europeus vieram aqui e quiseram construir, como o primeiro-ministro do Estado de Israel disse, ele queria construir a Suíça do Oriente Médio. Então ele trouxe sótãos, que não funcionam muito bem para coletar neve, mas funcionam muito bem para coletar poeira. E os pinheiros, que só estão ali para fazer com que pareça a Suíça, mas pinheiros destruíram muito das nossas terras agrícolas, como áreas de pastagem e tal. Eu moro em uma cidade chamada "O Campo do Pastor", Beit Sahur. Então o pastoreio é uma das profissões mais antigas que temos aqui. Como que 350 milhões de pinheiros foram plantados na superfície da $\mathrm{Pa}$ lestina para cobrir muito da terra, fazendo parecer um lugar europeu, para deixar europeus confortáveis na Palestina. Eles chamam isso de civilização da mesma maneira que exploradores do Brasil chamariam monocultura de uma forma de civilização, mas na verdade é exploração e destruição da terra e do meio ambiente. E eu quero dizer que nacionalistas judeus colocaram o rótulo "Israel" em toda a Palestina. Então, o que comemos, parte da nossa língua; tudo que eles gostam de nossa cultura, eles roubam, colocam outro rótulo e chamam de israelense. Tudo. Como é que uma entidade de 73 anos tem toda essa cultura rica? É roubada. É assim que... é tão simples assim. Quero dizer... sabe, o que eu sei, o que eu vejo em comum entre aqui e Brasil é que vocês são governados por uma pessoa idealista com uma ideologia fascista. E nós somos governados por pessoas que fizeram essa ideologia, a ideologia do Estado, e não é para chocá-los, mas tenho que lembrá-los de que o seu fascista pertence à esquerda liberal no espectro político israelense. Se o Bolsonaro viesse aqui, concorresse nas eleições e ganhasse, ele 
seria considerado um político israelense de esquerda, eles têm sangue nas mãos, dos fundadores do Estado de Israel até o último primeiro-ministro, até o próximo primeiro-ministro, que disse que sim, ele matou árabes, ele matou palestinos, e ele não vê problema com isso, sabe, ele se tornou primeiro-ministro do Estado de Israel sobre as caveiras de 15 mil mártires palestinos. Eu duvido não saber a respeito de Bolsonaro gostar de matar pessoas, mas mesmo assim, ele ainda é de esquerda, ele ainda pertence à esquerda no espectro político israelense. O que fazer, eu não gosto que as pessoas achem que a realidade sombria vai durar para sempre. Não, se você vive na Palestina, você vive em uma cultura que vem evoluindo há milhares de anos. E você vive em um lugar que foi regido por 23 grandes civilizações, que governaram essa geografia por mais de 200 anos, digamos. Então nós temos 23 dessas civilizações que subiram ao poder e colapsaram, deixaram a maioria dos opressores sobre elas, deixaram recursos, boas marcas e histórias terríveis. Então para mim, eu sei, opressão e injustiça não são sustentáveis na Palestina, nem um pouco sustentáveis. Dito isso, o único jeito dessa opressão terminar, simplesmente, será por sanções. Não há outra maneira. Eu digo às pessoas no Brasil, e digo isso hoje, se você acordar no Brasil e vir que há um embaixador israelense em seu país, lembre-se que esse é outro dia de opressão do povo palestino. O Estado de Israel pode bancar a opressão do povo palestino simplesmente porque tem relações econômicas, diplomáticas e militares com países ao redor do mundo. É isso. Essas relações têm que terminar se realmente quisermos viver em uma situação em que todos nascemos livres e iguais no território da Palestina.

[SG] Baha, foi tão bom ouvir o chamado para oração. Senti muitas saudades. [...] 
[BH] Eu moro ao lado de uma mesquita e de uma igreja, então é muito bom. Dito isso, tenho que dizer também que as pessoas no Brasil acham que todos nós somos muçulmanos, sem saber que somos uma população bem diversa. Sabe, esta é uma barba marxista, eu sou ateu. Bem, esta é uma barba marxista. Porém quando alguém me via, dizia “ah, é só outro palestino”, o que é besteira, mas vocês deviam saber que somos vendidos através das lentes e olhos de nossos opressores e não com base em nossa verdadeira existência.

[SG] Verdade. Para repetir, palestinos são um grupo diverso de pessoas. Existem muçulmanos, cristãos, judeus e também ateus. Todos eles. Eu só acrescentaria duas coisas. Porque aqui temos três pessoas veganas falando, e acho que muitos/as veganos/as vão assistir isso, pois eles/elas são a maior parte da minha audiência, e acho que temos um papel grande a cumprir nesse momento, porque veganwashing está sendo usado de um jeito que faz as pessoas ao redor do mundo esquecerem todos os crimes que Israel comete, ou vem cometendo, já há muito tempo, décadas. E eu queria dizer que... não em meu nome. E é triste porque, como uma pessoa vegana, e também lésbica, eu vejo a mesma coisa com a comunidade LGBT. Temos esses dois washings, veganwashing e pinkwashing. E Israel se apresenta como um lugar moderno e progressista, um paraíso para veganos e para LGBTs, "venha, nós temos uma parada LGBT" e "vocês têm parada LGBT na Palestina"? e eles sempre apresentam isso como "olhe como somos modernos e esclarecidos", "não pode ser verdade que nós estejamos cometendo crimes de guerra e crimes contra a humanidade, porque amamos gays, e amamos veganos". O que não é verdade, a propósito, como eu disse, é uma ferramenta de marketing. Mas então eu quero pedir, pessoas que são veganas e estão assistindo isso ou irão assistir, que apenas tomem cuidado para não se tornarem uma ferramenta que 
irá servir os interesses dos colonizadores. Não se deixem ser usados como armas para purificar crimes israelenses e para ajudar esse regime criminoso a continuar cometendo crimes sem sanções algumas. Então, existe um grupo bem legal. É bem pequeno e novo, chama-se "Vegans for BDS", e um dos meus queridos amigos palestinos, Ahlam, é parte dele. Então temos... eles têm uma conta de Instagram chamada "Vegans for BDS". O mesmo para o pinkwashing, existe o "Pink Watching". É um grupo que monitora todas essas coisas, um grupo LGBT que fica de olho em toda a bobagem propagandística que Israel engendra para atrair pessoas LGBT para lá. Então, não deixemos que nos usem para atenuar os crimes e a opressão contra a população palestina. Então, [existe] o boicote do BDS (Boycott, Divestment, Sanctions; em português, Boicote, Desinvestimento e Sanções), e claro, a campanha maior do BDS; há um grupo do BDS no Brasil. Você também os encontra no Instagram e Facebook, onde você pode ver que tipo de projetos estão acontecendo, e claro, devemos pressionar nosso governo a cortar os laços militares com esse regime criminoso que chamamos de Israel.

[FAGO] Muito obrigado Baha e Sandra; nós - eu e Daniela estamos muito honrados de estarmos com vocês aqui hoje. Muito obrigado pelo seu tempo. E para fazer acontecer, estamos fazendo esforços para espalhar essas palavras. Essa entrevista será postada em nosso canal no YouTube, o canal do nosso Laboratório, o "Laboratório de Ética Ambiental e Animal". Iremos colocar legendas em português e vou ver se se conseguimos colocar outras legendas, para que outras pessoas da América Latina possam assistir. É uma possibilidade. Espero, esperamos que esse seja somente o começo de uma série de entrevistas, para que as pessoas no Brasil e na América La- 
tina possam entender e apoiar a Palestina. Então, muito obrigado novamente e espero vê-los de novo aqui no Brasil, na Palestina e ao redor do mundo lutando contra qualquer tipo de opressão. Obrigado.

[DR] Muito obrigada. Cuidem-se.

[SG] Terminamos assim. Muito bom.

[BH] Desculpem-me, pensei que iríamos terminar... terminando. Então, a propósito, estou gravando isso para vocês.

[DR] Sim, obrigada. De novo, obrigada. É muito bom estar aqui com vocês e, como o Fabio disse, espero que seja o primeiro de muitos. Muito obrigada. Cuidem-se, e Palestina livre.

[SG] Muito bem. Palestina livre! 